KOLLÁNYI BENCE

\title{
A mobilcégek mantrájától a kikerült radarokig
}

\section{Szerzői információ:}

\section{Kollányi Bence}

Médiaszociológus, az ELTE Társadalomtudományi Karán szerezte szakirányú képesítését. Az Információs Társadalom- és Trendkutató Központ munkájában 2004 nyarától vesz részt, 2005 szeptemberétól junior kutatóként dolgozik. Fő érdeklôdési területe az információs társadalom mérhetôvé tétele, a felkészültségi rangsorok, valamint a kormányzati információs társadalom stratégiák elemzése. Az Infinit hírlevél Információs politika címü rovatának szerkesztôje.

E-mail: kollanyi.bence@ittk.hu

Így hivatkozzon erre a cikkre:

Kollányi Bence. „A mobilcégek mantrájától a kikerült radarokig”.

Információs Társadalom VIII, 1. szám (2008): 119-122.

— https://dx.doi.org/10.22503/inftars.VIII.2008.1.15

A folyóiratban közölt müvek

a Creative Commons Nevezd meg! - Ne add el! - Így add tovább! 4.0

Nemzetközi Licenc feltételeinek megfelelően használhatók. 


\section{INFINITI HÍRLEVÉL}

Kollányi Bence

\section{A mobilcégek mantrájától a kikerült radarokig}

Erich Moechel médiakritikus és újságíró, többek között az ORF Futurezone szerkesztöje. A vele készült interjúban - egyebek mellett - a mobiltársaságok adatkezeléséról és a kormányok terrorizmus elleni harcának sajátosságairól kérdeztïk.

A linzi Ars Electronica fesztivál résztvevôi évról évre a tudomány és múvészet eszközeivel keresik a technológia és a társadalom átalakulása közben felmerült aktuális kérdésekre a választ. A hagyományoknak megfelelően minden évben hangzatos jelmondattal adják meg az esemény alaphangját. Az idén a résztvevók a magánszférától vettek búcsút... Ennek apropóján kérdeztük Erich Moechelt.

Kollányi Bence: Elöadásában utalt arra, hogy a mobilcégek többsége folyamatosan elemzi az elöfizetók kommunikációs szokásait. Példaként emlitette, hogy a felhasználók hivásainak analizálásával felismerhetốk a társaság elhagyására készülö ügyfelek. Ugyanakkor az adatbázisok felépitése és elemsése a társaságok számára jelentớs költségekkel jár: Ön szerint megéri a befektetés? Illetve milyen más hozadéka van az elemzéseknek?

Erich Moechelt: Ez elsősorban azért hasznos a szolgáltatóknak, mert a piacok telítôdésével egyre nagyobb a verseny. Ha növekedni akarsz, nem teheted meg anélkül, hogy másoktól ne hódíts el ügyfeleket. Ezért a mobilszolgáltatók minden lehetséges, az elófizetốk viselkedését elớre jelzó információt megpróbálnak kinyerni adatbázisaikból. Meghatározott alakzatok után kutatnak. Az alapvetố kérdés pedig nem más, mint az, hogy „a felhasználó meg fogja-e változtatni telefonálási szokásait, hajlik-e arra, hogy elhagyja a társaságot”. Erre jó példa, ha egy előfizetố olyan szolgáltatásokat vesz igénybe, amelyeknek segítségével a hívások olcsóbb szolgáltatásokon keresztül futnak. Ez ugyanis ellenkezik a mobilcégek mantrájával. Tudja, mi az?

K. B.: Nem.

E. M.: ARPU, Average Revenue per User (egy elófizetóre jutó átlagbevétel), ez a mantrájuk. Ezt akarják növelni, ezért bármit hajlandók megtenni. Különböző okokból figyelik az elófizetóket. Az egyik, már a korábban is említett jelenség, hogy igyekeznek megtalálni azokat az ügyfeleket, akik a hívásaik alapján jó eséllyel el akarják hagyni a társaságot. Ezt követóen üzletkötóket küldenek hozzájuk, akik ilyenkor rendszerint visszautasíthatatlan ajánlatot tesznek. Elóbb ugyanis részletesen megvizsgálják az elófizetố kommunikációs szokásait, csak ezután tesznek ajánlatot. Ahogy ez meg is történt Olaszországban a Telecom Italia esetében, de mindenhol hasonlóan múködik a rendszer. Van továbbá egy másik adatbázis is minden mobilszolgáltatónál, amelynek segítségével a lehetséges visszaéléseket igyekeznek kiszúrni. 
K. B.: Azokra a felhasะnálókra gondol, akik hatalmas tartozásokat halmoznak fel, és ast késóbb nem fisetik meg?

E. M.: Igen. Ez az egyik legnagyobb problémája a szolgáltatóknak. Az egyes ügyek kivizsgálása mindenképpen veszteséget okoz a társaságnak. Ráadásul sok esetben akkor sem tudnak fizetni az ügyfelek, ha bebizonyították tartozásukat. Ezért a cégek igyekeznek minél korábban kiszúrni ezeket a felhasználókat, hogy a lehetô leghamarabb közbeléphessenek, csökkentve ezzel veszteségeiket. Biztos vagyok, hogy ezen igyekezetük közben az európai adatvédelmi törvényeket napi rendszerességgel hágják át a mobilszolgáltatók. Az ok ismét ugyanaz, az egy előfizetốre jutó átlagbevétel növelése.

K. B.: Több adatbázist és elemzöszoftvert is emlitett, amelyeket a mobilszolgáltatók kiépitenek és alkalmaznak. Ennek ellenére, ha a kormányzat - például a terrorizmus elleni harcra hivatkozva - azt kéri a szolgáltatóktól, hogy tovább tárolják az elófizetók hivási adatait, a társaságok gyakran arra hivatkoznak, hogy ez jelentós többletköltséggel jár. Az Ön elmondása szerint azonban a szolgáltatók maguk is érdekeltek az elófizetói adatok minél hosszabb ideig tartó tárolásában.

E. M.: Egészen addig tiltakoznak, ameddig meg nem kapják a kormányzattól a várt ellentételezést. A mobilszolgáltatók egyszerúen el akarják adni mindezt a kormányzatnak egyfajta szolgáltatásként, és megfelelő fizetséget akarnak kiharcolni. Ennek megfelelően elutasítják az elsố ingyenes ajánlatokat. Ha visszaemlékezünk, a kezdeti idókben a szolgáltatók nem is rendelkeztek az adatok elemzéséhez szükséges szoftverekkel, mert azon dolgoztak, hogy megalapozzák a hálózati infrastruktúrájukat. De mihelyt többé-kevésbé befejezôdött a hálózatépítés, elsôsorban az adatelemzésbe kezdtek el befektetni a társaságok. Rengeteg olyan szoftver és hardver létezik ma a piacon, amely kiszolgálja a telefontársaságok igényeit. Így beszerezhetố visszaélés-elórejelzố (Fraud Management Tool) vagy a már említett potenciális szolgáltatóváltást elốrejelzó megoldás is, továbbá ott vannak a kormányzati adatkéréseket kiszolgáló alkalmazások. Az elmúlt néhány évben ezek mélyen beépültek a mobilhálózatok struktúrájába, s a mobilhálózatok ennek megfelelóen nyitottá váltak.

\section{K. B.: Jól értem, hogy olyan kiskapukat épitettek a hálózatba a szolgáltatók, melyek segitségével a kormányzati igényeket szolgálhatják ki? Tehát harmadik félnek adhatják ki az elófizetôi infor- mációkat?}

E. M.: Pontosan. Nézze, szükségük van egy olyan felületre, ahol adatokat tudnak szolgáltatni. Ez a felület nem jut más szerephez a mobilhálózatban. Ez valami furcsa, idegen elem a rendszerben, hiszen alapvetóen az lenne a cél, hogy a hálózat minél zártabb legyen. Ennek a zárt hálózati logikának mond ellent az a fejlesztés, amelynek egyetlen célja, hogy kiemeljen a rendszerból bizonyos információkat egy harmadik fél számára. Ezek a felületek rettenetesen sérülékenyek, bárki, aki ismeri a múködésüket, könnyedén betörhet a hálózatba. Nemrégiben Görögországban tört ki botrány, mivel olyan személyes adatokat és információkat árultak, amelyeket mobilhálózatok adatbázisaiból nyertek ki. Ezekre az adatokra pedig komoly kereslet van manapság. 
K. B.: Mi a szerepe az egész folyamathan a sztenderdizációnak? Elóadásában ezt a teriiletet is érintette, de nem pontosan értettem a párhusamot.

E. M.: Ez egyszerú. Minden nagyobb társaság, különösen a több országban hálózattal rendelkező társaságok érdekeltek abban, hogy az egész hálózatukon belül ugyanazt a technológiát alkalmazzák. Nézzük a Deutsche Telekom példáját: úgy tudom, ók rendelkeznek Magyarországon érdekeltségekkel, megvették a Matávot. Tehát a Deutsche Telekom, illetve a T-mobile érdekeltek abban, hogy ugyanazokat az eszközöket használják, azonos jogszabályi környezetben. Így olcsóbb a hardverek beszerzése, csökkennek a szoftverek fejlesztési költségei, kevesebbe kerül a rendszer fenntartása. Ezért a mobiltársaságok alapvetốen érdekeltek a sztenderdizációban. Az ezzel foglalkozó bizottságokban természetesen a megfigyelési eszközöket gyártó cégek és a harmadik érdekelt csoport, a rendốrség és az állambiztonság képviselói is jelen kívánnak lenni - ók a technológia kínálta lehetôségeket akarják kihasználni. A modern hálózatokban központi hozzáféréssel lehet a leghatékonyabban hozzájutni az adatokhoz. Van persze más lehetôség is. Például egy személy követésekor erre szolgál az IMSI (International Mobile Subscriber Identification) catcher: Ez egy apró eszköz, amely mobil adótoronyként múködik. Minden mobiltelefonnak van egyedi azonosítója (ez az IMSI), akár elófizetéses, akár kártyás készülékról beszélünk. Ha az IMSI catcher közeléból indít valaki hívást, elsóként a kis jeladót érzékeli a telefonja: ez a klasszikus man in the middle (MITM) attack. Ehhez persze a megfigyelést végzô embernek ugyanabban a cellában kell lennie. Az IMSI catcher a telefon felé toronyként jelentkezik, a torony felé pedig mobiltelefonként viselkedik. Ez a mobiltársaság központjából sem látható. Egyébként, ha egy ilyen eszközt a parlament közelében helyezünk el, akkor az jelentôs állambiztonsági kockázatot jelent.

\section{K. B.:Azemberek ezekröl a veszélyekröl mit sem tudnak. Hogyan látja Ön, mennyiben jelentheti a megoldást a felhasználók tájékoztatása? Az információk átadása mellett a jogszabályokat is módosithatják, illetve olyan megoldásokat kinálhatnak, amelyek segitik a felhasználók anoni- mitását, elrejtơzését. Ön szerint a három lehetséges válasz közïl melyiknek van a legnagyobb je- lentósége?}

E. M.: Nos, a jogszabályok jelenleg éppen az ellenkező irányban változnak, a helyzet egyre rosszabb. Ennyit a jogszabályokról, ehhez talán nincs is mit hozzáfúzni. A második kérdés az emberek tájékoztatása. Igen, ez lassan elkezdôdött, az emberek kezdik megérteni, hogy nem a beszélgetéseik lehallgatása miatt vannak veszélyben. Viselkedési mintázataikat vizsgálják, ami, ha lehet, még rosszabb és többet árul el a személyról. Megtudhatjuk, hogy kiról van szó, kikkel kommunikál, milyen szociális háló veszi körül. Ez olyan veszély, amellyel még nem is számolnak az emberek. A kommunikációs szokások alapján profilokat alakítanak ki. Az anonimitásról és a titkosításról: mivel itt hívási adatokról van szó, azt kell mondanom, hogy a titkosítás nem sokat ér. Ha titkosítanánk a kommunikációnak ezt a részét, akkor a mobiltársaság nem tudná kapcsolni a hívott számot.

K. B.: Ezek szerint nem egyszerüen informálásról van szó, hanem a tudatosságot kell növelni az emberekben? 